\title{
La ciudad de las derivas: Lima vista por el cine peruano del nuevo siglo*
}

\author{
Ricardo Bedoya \\ (Universidad de Lima, Perú)
}

Recibido: $1 / 4 / 2015$

Aprobado: 2/6/2015

\begin{abstract}
RESUmen. A pesar de que la visión de Lima ofrecida por el cine peruano se fue modelando con el transcurso de las épocas y las sensibilidades, algo se mantuvo constante desde la década de 1930: la representación cinematográfica de la capital del Perú mantuvo un vínculo esencial con el imaginario costumbrista, su exaltación de los modos de vida tradicionales y la nostalgia por aquello que la ciudad perdía con la llegada de la modernidad. Pero lo sustancial de esa mirada se transforma con el advenimiento del nuevo siglo y la irrupción de una promoción de cineastas que se embarca en el tránsito hacia lo digital, en tiempos de liberalismo económico y "posconflicto", y se perfilan cuestionamientos a las imágenes del pasado.
\end{abstract}

Palabras clave: ciudad / costumbrismo / criollismo / deriva / digital / distopía / limeñismo / periferia / posmemoria

\section{City of drifts: Lima seen by Peruvian Cinema of the New Century}

Summary. While the vision of Lima put forward by Peruvian cinema has been shaped over time and according to the corresponding sensitivities, something has remained unchanged since the 30s; i.e. the cinematographic representation of Peru's capital has preserved a critical liaison with the costumbrist imaginary, the exaltation of the traditional ways of life and the nostalgia for what the city has relinquished to the advent of modernity. The essence of such view, however, was transformed with the arrival of the new century and the emergence of a group of filmmakers who are moving towards the digital era in times of economic liberalism and a "post conflict" era. In this context, the questioning of past images takes the center stage.

Key words: city / costumbrismo / criollismo / drift / digital / dystopia / limeñismo / periphery / postmemory

* Este artículo toma como base para su redacción asuntos trabajados en la investigación "El cine peruano en tiempos digitales", realizada por el autor con el auspicio del Instituto de Investigación Científica de la Universidad de Lima, y publicada por el Fondo Editorial de esta casa de estudios (2015). 
- Cuántas representaciones de Lima, capital del Perú, ha ofrecido nuestro cine a lo largo de su historia?

Múltiples, claro, de acuerdo a las épocas y sus sensibilidades. Una mirada retrospectiva nos muestra la ciudad criolla y de festivo costumbrismo -con un dejo de nostalgia- de las películas de Amauta Films; la Lima de la agitación rumbera en la plaza San Martín de los años cincuenta; la de la modernidad de la residencial San Felipe y el aeropuerto Jorge Chávez, emblemas del primer gobierno de Fernando Belaunde Terry, presentes en el cine de Robles Godoy y las comedias peruano-mexicanas de los años sesenta; la del neocostumbrismo de los cineastas surgidos con la ley dada por el gobierno militar de los setenta; la del "desborde popular" de los ochenta, tal como la registró el Grupo Chaski en Gregorio y Juliana (tomo el término de Matos Mar, 1984); la ciudad inhóspita, violenta, infernal y carcelaria que impulsaba a los personajes a emprender una fuga sin fin durante los años noventa; entre otras.

Esas son solo algunas imágenes que el cine peruano ofreció de la capital del Perú en las décadas anteriores.

En tiempos de tránsito hacia lo digital, desde los inicios del siglo XXI, las representaciones cinematográficas de Lima se definen por el contraste y la crítica a esas representaciones del pasado.

El criollismo se pervierte, "nuevos sujetos" transitan por la ciudad como personajes flotantes, y Lima aparece imaginada en una distopía de ciencia ficción. Las películas de Daniel y Diego Vega, Eduardo Mendoza de Echave, Josué Méndez, Héctor Gálvez, Eduardo Quispe, Adrián Saba, entre otros cineastas del nuevo siglo, trazan cartografías alternativas para navegar por una Lima que el cine de hoy convierte en un espacio de múltiples derivas.

¿Qué entornos tecnológicos, sociales y culturales han acompañado, o condicionado, el surgimiento de esas nuevas miradas sobre Lima?

En primer lugar, cuenta el impacto del advenimiento de la revolución digital. La disponibilidad de las cámaras y los programas de edición impulsan, desde el año 2000, el surgimiento de una vasta producción de películas, realizadas apelando a diversos sistemas de financiación. Encontramos títulos que aspiran a su difusión masiva en multisalas, así como otras que deben sus existencias al resultado del trabajo en microsistemas de producción. Desde cintas de "autor" con impacto en festivales internacionales, hasta películas autogestionarias, de presupuestos mínimos, tecnología asequible, luz natural, sonido imperfecto, volcadas a la representación de los detalles de la vida cotidiana y el habla coloquial.

Los cineastas que irrumpen con el nuevo siglo han aprovechado con intensidad los tres "menoscabos" para el "cine" (como institución) que trajo consigo la revolución digital: su desacralización (las imágenes y sonidos ya 
no son el patrimonio de profesionales), su desmaterialización y su diseminación: las imágenes y sonidos circulan libremente por múltiples pantallas (Gaudreault y Marion, 2013).

Lasimágenes de Lima, de sushabitantes y prácticas cotidianas, están presentes en esas películas, con independencia de la envergadura de la producción. Las encontramos en jAsu Mare! (2013), pero también en las películas que tientan una suerte de "retorno a lo básico", como afirmando la ética del cine hecho entre amigos y por uno mismo (Rombes, 2009).

En segundo lugar, son películas que se producen y realizan durante el período que corresponde a las "transformaciones de la era neoliberal y el posconflicto" (Del Pino, 2013, pp. 16-17).

En otras palabras, surgen en el entorno del régimen cultural que se construye teniendo como sustento los principios de un mercado desregulado, según las normas que diseñan el modelo liberal de la economía peruana, dictadas durante el gobierno de Alberto Fujimori, a inicios de los años noventa. Y se realizan en el período que sigue al conflicto armado interno provocado por la insurgencia del Partido Co- munista del Perú, Sendero Luminoso, de ideología maoísta, al declarar una "guerra popular" contra la sociedad peruana en 1980.

Como consecuencia de esos fenómenos, la ciudad acoge -no siempre de modo hospitalario- a los desplazados de la violencia, migrantes forzosos, y a sus descendientes, que construyen nuevas formas de convivencia y manifestaciones culturales en la ciudad, como en las décadas anteriores lo habían hecho ya migrantes llegados en otras circunstancias.

Los "nuevos limeños", o los limeños emergentes, como se les denomina en los estudios sociales (Portocarrero, 1993) y en las prácticas de la mercadotecnia para designar a los nuevos sujetos del consumo en la ciudad, se convierten en personajes de la ficción cinematográfica (Arellano, 2004).

Triunfadores o no; emprendedores o pasivos; sujetos del cambio o desconcertados ante los nuevos tiempos, esos limeños son testigos de los espacios creados por la expansión de la ciudad, la especulación inmobiliaria y el deterioro de los lugares tradicionales, imágenes de marca de Lima hasta los años setenta ${ }^{1}$.

1 Se pueden contrastar los cambios en las percepciones de la Lima tradicional en dos películas emblemáticas del periodo: Las malas intenciones (2011), de Rosario García Montero, y La teta asustada (2009), de Claudia Llosa.

En la primera, Cayetana, la niña protagonista, vive la experiencia del crecimiento y la película se ancla en su punto de vista. Las acciones transcurren en el verano de 1983, tiem- 
Películas como La lucha por un sueno (2004) o Motor y motivo (2009) muestran a los protagonistas satisfechos con su destino y asimilados en la ciudad. Otras películas, en cambio, representan a limeños en tensión con su medio. Lima se convierte en el escenario de sus derivas, en un lugar de desencuentros permanentes. En títulos como Octubre, El mudo, El evangelio de la carne, Días de Santiago, Paraíso, Chicha tu madre, 1, 2, 3, 4, 5, El limpiador, entre otras,

la ciudad es como un palimpsesto en el que se inscribe una y otra vez el mismo recorrido (la deriva), en el que se escribe el mismo texto, con variantes: el del sujeto posmoderno, un sujeto flotante, de relaciones líquidas, que ha perdido las referencias, tanto espacio- temporales como simbólicas, un sujeto borderline (Imbert, 2010, p. 266).

Pese a mostrar un presente insatisfactorio, esas películas se resisten a evocar el pasado para idealizarlo. De ellas tratamos aquí.

\section{Recusando el costumbrismo}

Octubre (2010), de los hermanos Daniel y Diego Vega, es el retrato de un personaje y una ciudad: de Clemente (Bruno Odar), prestamista impenetrable y de pocos escrúpulos; y de Lima y sus espacios tradicionales durante el mes de octubre.

La línea argumental enfrenta al hierático Clemente con una niña que

pos de convulsión social y violencia política. Los familiares de Cayetana, miembros de la burguesía acomodada de Lima, se enfrentan a la realidad de estar perdiendo -o de haber perdido ya- el control de sus recursos, fortunas, tiempos y lugares de ocio. El balneario costeño de Ancón, espacio vacacional y entrañable de otrora para la burguesía limeña, luce desbordado por vecinos desconocidos, foráneos. El malecón y la playa condensan las impresiones del deterioro físico, signos finales de una época. Las imágenes de los bañistas, registradas con focales largas, restando profundidad visual al encuadre, refuerzan la sensación de asfixia, saturación y extrañeza. La lancha que conduce a la familia de Cayetana hasta la embarcación de recreo es empujada por niños llegados de otros lugares: son los hijos de la migración interna. Nadie los llamó, pero están ahí y son movidos por un impulso que no se puede detener.

En La teta asustada, Fausta, la protagonista, hija de una desplazada ayacuchana y traumada por la violencia que vivió su madre, víctima de una violación en tiempos del conflicto armado interno, empieza a trabajar como empleada del hogar en una residencia señorial de Lima. De estilo clásico republicano, la casa de la señora Aída se yergue como un castillo amurallado, con puerta levadiza que separa el lugar de un populoso mercado. Dentro de la casa domina una atmósfera severa que contrasta con el espacio de afuera, ruidoso y colorido. La residencia se encuentra separada de la calle por un extenso jardín y un muro. El lugar es una reserva del pasado, una propiedad mantenida al resguardo del desorden informal que ha tomado en rehén a la ciudad. 
es abandonada en su casa. Esa situación es el punto de partida de una indagación por los rostros y apariencias de personajes esperpénticos, limeños de la cotidianidad, ubicados frente a escenografías del deterioro.

Buscando a la madre de la niña abandonada, Clemente debe recorrer las calles de Lima. Las imágenes de su deriva adquieren un valor metonímico: son las partes de un todo más amplio y anacrónico. Las tradicionales quintas y callejones del Cercado se encuadran de modo frontal, manteniendo un rigor simétrico en la composición visual. Conservando fijeza y estabilidad, la duración de los encuadres se dilata, acaso para dar a los personajes un tiempo de arraigo en esos lugares que lucen una fría luminosidad.

Cada uno de esos ambientes limeños puede ser reconocido con facilidad. Es el de las calles, esquinas y ambientes que encarnaron el limeñismo -o el espíritu de la ciudad tradicional- de otras épocas. Pero aquí se evitan las identificaciones festivas o las complicidades emocionales propiciadas por la imaginería costumbrista. La película es la representación monocroma de un mundo opaco.

Hagamos un racconto. ¿Cómo fue la tradicional representación audiovisual de esa Lima antigua, la del Cercado y las zonas del Rímac y Barrios Altos, o de los barrios de la clase media empobrecida?

Fue una representación inscrita bajo el signo del costumbrismo criollo, herencia del teatro popular del siglo XIX y del "género chico" de variedades musicales y cómicas, de las viñetas localistas y la sátira amable.

Los rasgos centrales de ese talante, entre festivo y nostálgico, toman cuerpo y definición en las películas limeñas producidas entre 1937 y 1940 por la empresa Amauta Films. Un período en el que se intenta consolidar la industria cinematográfica en el Perú en los albores de la era sonora que, entre nosotros, arranca en 1934. Empeño frustrado, por cierto.

La representación de la Lima tradicional es central en esas películas. Las configuraciones de los barrios y las diferencias sociales de sus vecinos son los rasgos que ambientan y sitúan sus tramas. Ellas convocan a la nostalgia por los tiempos pasados, pero llaman también a la jarana. Lamento y celebración, combinados, como en las películas de la robustecida industria mexicana de los años treinta y cuarenta. Títulos como Almas en derrota, Palomillas del Rímac o Esa noche tuvo la culpa alternan el sufrimiento con la euforia; los personajes lloran la separación amorosa o la indeseable aparición de una enfermedad para luego entonar valses y rasguear guitarras. Las esquinas de Breña o el Rímac, escenarios de la ficción, se reconstruyen en algún set edificado al menor costo posible.

El clima de esa época es turbulento y está marcado por cambios sociales acelerados. Hacia fines de los años treinta, Lima pierde su fisonomía tra- 
dicional, centro neurálgico de las manifestaciones de la cultura criolla. Se demuelen solares y se amplía el empleo asalariado. Las rutinas de la vida hogareña se alteran al extenderse la proletarización. Las películas de Amauta Films no registran esos cambios con el acento del testimonio documental. Lo hacen de manera indirecta, ensalzando el pasado de una Lima asaltada por un presente agresivo y en camino hacia un futuro incierto.

Lo mismo ocurre años después, al culminar la década de los cincuenta, en los inicios de la televisión peruana, cuando Jorge "Cumpa" Donayre y Benjamín Cisneros escriben guiones al alimón bajo el seudónimo de Juan Renteros, y crean una topografía criolla, la del típico bar del barrio, en un programa llamado Bar Cristal, emitido por América Televisión. Es el nacimiento de la ficción costumbrista en la televisión, ya que Bar Cristal recrea la vida idealizada en un antiguo barrio de Lima, donde se escenifica la tragicomedia de los sentimientos ${ }^{2}$.

Fin del racconto.

Octubre, la película de los hermanos Vega, alude desde su título a lo típico, lo capitalino y lo local: la evocación del festivo y piadoso "mes morado" limeño. Su asunto transita el territorio de la ficción costumbrista. Sin embargo, el tratamiento fílmico desmonta las convenciones del naturalismo y el color local y revierte la tipicidad en la representación de la Lima criolla.

Lo hace rehuyendo la exaltación de lo "nuestro" y la efusión limeñista del mes del Señor de los Milagros, pese a que todos los elementos propios del cuadro criollo se encuentran ahí: desde el hábito morado de Sofía (Gabriela Velásquez) hasta los turrones de Doña Pepa que prepara como uno de sus recursos de supervivencia, pasando por las imágenes de la procesión con sahumadoras y penitentes.

Pero todos esos elementos no se exhiben como pruebas de autenticidad ni como objetos de ilustración para una crónica local, ni como argumentos para exaltar el orgullo regional. El tratamiento de estilo impone un efecto de distanciación que erradica los guiños de complicidad con lo festivo. Las calles de Lima, las quintas, el hospital de salud pública y los ambientes nocturnos que recorre Clemente en su búsqueda de la madre de la niña abandonada, poseen un aire de extrañeza, un aspecto lunar y hasta melancólico. Aparecen como los escenarios

2 Bar Cristal fue un programa clave en el proceso de formación de las audiencias para la televisión peruana. Sus emisiones ofrecían una representación del sentimiento de lo "peruano" como manifestación exaltante de la identidad criolla y la idiosincrasia urbana; es decir, limeña. Bar Cristal se emparentaba con el espíritu de las películas producidas por Amauta Films entre 1937 y 1940. Lo criollo se percibe en ellas como la manifestación de un modo de ser citadino y popular. 
subsistentes de alguna catástrofe de ocurrencia remota, acaso inadvertida por sus habitantes. Los restos de un apocalipsis silencioso.

La estilización de las formas cinematográficas transforma la percepción de la realidad urbana. La Lima de los hermanos Vega no es una urbe frenética ni detonante. Es, más bien, un lugar suspendido en un tiempo impreciso.

El formato panorámico de la proyección resalta la disposición de los personajes y objetos del campo visual en el eje horizontal de la composición del encuadre, lo que da a la imagen una regularidad y una simetría que apuntan a la abstracción. Ello afinca a los personajes en sus entornos más próximos: las inquietudes del prestamista se amplifican en esos lugares desastrados, con paredes humedecidas y desconchadas, estuco cuarteado y mobiliario raído. La presencia de Robert Bresson y la escueta materialidad de los espacios y mobiliarios de sus películas se encuentra con la radical extrañeza de las calles y los ambientes que hallamos en el cine de Aki Kaurismaki.

Pero el desmontaje del gesto costumbrista se hace patente también en el diseño de los personajes.

Los limeños que protagonizan $O c-$ tubre tienen más rasgos compartidos con los personajes de la novela realista europea del siglo XIX que con los criollos del cine de los años treinta o con los jóvenes del neocostumbrismo urbano desde los años setenta; es decir, desde
Cuentos inmorales (1978) hasta Quizás mañana (2013) o Japy ending (2014).

Los hermanos Vega apuntan a la estilización de lo anacrónico: no pretenden mantenerse en sintonía con los tiempos actuales de orgullosa modernidad ni encarnan una manera de ser contemporáneos, tampoco apelan al coloquialismo de aquí y de ahora.

Sus historias dan cuenta de pasiones, defectos o virtudes que resultan intemporales o se hallan extraviadas en el tiempo. Los personajes encarnan la cara opuesta del emprendedor, ese sujeto emblemático en tiempos de acumulación individualista. Los utensilios que encontramos en los espacios de sus películas están en las antípodas de lo que imponen las exigencias del consumo, los reclamos publicitarios, y repiten los discursos oficiales sobre la prosperidad económica: se muestran destartalados o decrépitos, como el mobiliario del hospital o el de las casas de Clemente y Sofía. Una lupa es el objeto que intermedia entre Clemente, los objetos entregados en prenda y sus clientes prestatarios. La lupa, el instrumento que encarna la idea de la usura en su representación dramática canónica.

En el segundo largometraje de los hermanos Vega, El mudo (2014), seguimos el periplo de Constantino Zegarra (Fernando Bacilio), juez de primera instancia en lo penal, un hombre honesto y metódico. Disciplinado en su oficio, condena con el máximo rigor y ordena, de modo indefectible, la prisión efectiva para los inculpados. 
Si en Octubre el frío engranaje de la vida del prestamista se traba con la llegada inesperada de una niña, aquí el sistema se pone en crisis a causa de esa anomalía que es la conducta proba de un juez como Constantino. Él es un cuerpo extraño en el mundo de arreglos subterráneos, corredores interminables y expedientes apiñados en ese Palacio de Justicia de aparatosas reminiscencias arquitectónicas belgas, pero asentado en la Lima del Paseo de la República y alrededores, cerca de las calles Mapiri y Azángaro, territorios de desorden e informalidad donde se delinque contra la fe pública a ojos vistas.

Como en Octubre, los ambientes del deterioro se muestran en encuadres fijos y simétricos, con el desorden de los juzgados entrevistos desde las puertas estrechas de las oficinas. La metáfora urbana de la precariedad y la improvisación se esboza también en la representación de esos espacios colmados con expedientes judiciales preinformáticos, de lomos cosidos con hilo y aguja. Es una Lima plagada de anacronismos, donde la modernidad es una rémora.

En todos esos lugares, Constantino es un cuerpo ajeno, refractario a cualquier entusiasmo o ilusión. Sobre todo a las efusiones colectivas, las de la Marca Perú, o las que celebran la presencia de las autoridades económicas del país dando el martillazo inicial a la jornada en Wall Street, como lo informa una emisión televisiva.
Lima es, en el cine de los Vega, un lugar de esquinas anónimas y avenidas transitadas por automovilistas impacientes, siempre anónimos. Apenas si entrevemos, en una breve escena, la Lima plena del Estadio Nacional donde se corean arengas en algún partido que, de seguro, perderá el Perú.

El evangelio de la carne (2013), quinto largometraje de Eduardo Mendoza de Echave, está en las antípodas del estilo de las películas de los hermanos Vega. El hieratismo de Octubre y El mudo contrasta con la hiperactividad narrativa de El evangelio de la carne.

Sin embargo, ellas mantienen un vínculo: se ambientan en la Lima de las festividades tradicionales del mes de octubre.

Las acciones de El evangelio de la carne tienen como marco dos eventos masivos: el inminente final del campeonato de fútbol que enfrenta a los equipos rivales tradicionales, Universitario de Deportes y Alianza Lima, y la procesión del Señor de los Milagros.

Esos son los escenarios que activan el desarrollo de tres historias paralelas. La del policía Gamarra (Giovanni Ciccia), que realiza operaciones encubiertas en las calles de la ciudad y cuida a su esposa Augusta (Jimena Lindo), afectada por una dolencia terminal. La de Félix (Ismael Contreras), que aspira a pertenecer a la Hermandad del Señor de los Milagros porque cree que ese gesto le permitirá purgar una culpa que lo atormenta. La de Narciso (Sebastián Monteghirfo), 
que pretende mantener el liderazgo de una barra brava de Universitario de Deportes (la "U") mientras ayuda a su hermano, inculpado por un delito de lesiones graves e internado en un reformatorio.

Los personajes de este evangelio doloroso buscan resolver sus dilemas íntimos, teniendo como escenografía a una Lima saturada, hormigueante, siempre activa. Es la ciudad peligrosa que transitan los nuevos empresarios y los sicarios, los creyentes y los tramposos, y en la que se ha diluido la línea fronteriza que separa la legalidad del delito. La ciudad que induce a adoptar la ética del "vale todo" porque la precariedad existencial es el salvoconducto que autoriza a sus habitantes a plegarse a un orden concesivo, de lata tolerancia, que justifica la informalidad y el timo convertidas en reglas de convivencia ciudadana.

La acción, acezante, transita de los lugares abiertos a los espacios concentrados, de los climas luminosos a los ambientes sombríos. De los sitios privados, o de intimidad densa, se pasa, con seca energía, a los espacios tumultuosos de Lima: los mercados informales, los pasillos de una clínica, un cementerio, el jirón Ocoña, la avenida Tacna colmada, y los horizontes abiertos, vistos desde la altura y a la distancia, con los poblados y grises cerros que diseñan el perfil de la ciudad.

En el curso del relato se recorren los entresijos de la ciudad de Lima: los corredores laberínticos de un centro comercial informal; los tragamone- das; un ring de peleas clandestinas; el umbral en penumbras de una casa de cambios del Jirón de la Unión; el taller de impresión de billetes falsos; los lugares donde se ejercitan los actos de fe: los espacios donde se escenifican las liturgias de la adoración laica por la "U" y la devoción por el Señor de los Milagros. La fotografía de Mario Bassino diseña esas atmósferas emparentadas con las del film noir: la sordidez de las secuencias de apuestas ilegales y las de la imprenta se sustenta en la contrastada iluminación en estilo low key.

Se percibe una ambición totalizadora y un trasfondo documental, de acentos expresionistas, en El evangelio de la carne. Las tramas secundarias de la película conducen a los personajes por las zonas minadas de la ciudad donde se registran las experiencias del caos urbano y donde sujetos de todos los oficios encuentran un lugar para expresar sus demandas sociales: los creyentes y los huelguistas; los piadosos y los violentos; los policías y los traficantes; los extorsionadores y los apostadores; los traidores y los que optan por comportamientos de sacrificio. En este retrato abigarrado, el ápice de intensidad se halla en la secuencia final con las imágenes de Gamarra ofreciendo a su esposa, desfalleciente, a la imagen del Señor de los Milagros. En ese momento confluyen el registro documental de lo captado en un momento de verdadera apoteosis colectiva y el punto álgido de la situación melodramática. 
Octubre, de los hermanos Vega, y El evangelio de la carne desarrollan historias que transcurren en Lima durante el tradicional período de festejos religiosos en el mes de octubre. Ambas trascienden el costumbrismo y el realismo urbano. Los Vega lo logran a fuerza de contención y humor impávido. Mendoza, empujando las acciones hasta el extremo, sin temerle al patetismo ni al melodrama. Es decir, confiando más en la fuerza acumulativa y en las pulsaciones del relato que en la verosimilitud realista de cada situación por separado.

\section{El limeñismo en cuestión}

1 (2008), 2 (2009), 3 (2010), 4 (2011) y 5 (2014), de Eduardo Quispe Alarcón ${ }^{3}$, son películas emblemáticas de la vertiente autogestionaria del cine limeño, realizado sobre soporte digital, ajeno a cualquier subvención institucional y destinado a su exhibición en circuitos paralelos.

Ellas abordan, de modo frontal, los asuntos vinculados con el estar en la ciudad, el insertarse en sus espacios, pertenecer o ser ajeno a ellos, y del transitar en una suerte de constante y errático desplazamiento. Los protagonistas de las cinco películas son jóvenes, acaso universitarios, que ventilan sus afecciones, cuitas o desavenencias en largas conversaciones o mediante diálogos entrecortados.

Los cinco títulos muestran encuentros y separaciones entre personajes urbanos y solitarios, siempre flotantes, que parecen existir solo para dar cuenta de sus proximidades o discrepancias. Las películas dramatizan las relaciones afectivas entre hombres $y$ mujeres jóvenes de la clase media limeña provenientes de sectores populares.

En un momento de 1, el personaje principal, encarnado por el propio Eduardo Quispe, le dice a su interlocutora que detesta el distrito de Barranco y lo que significa ese lugar en el imaginario limeño, por su asociación con lo criollo. Más tarde, el mismo personaje expresa su disgusto por el ceviche, un plato que define la identidad de la gastronomía costeña.

Esas impugnaciones al criollismo de Barranco y al sabor del ceviche en una película con las características de producción y estilo que posee 1 , trascienden las menciones al distrito sureño, a su tradicional "movida" bohemia, y al culto del plato emblemático. Son, más bien, recusaciones al "limeñismo" o al criollismo, tal como fueron representados en el cine peruano del pasado, y gestos de resistencia o de oposición a las ficciones con personajes típicos, designados por sus extracciones sociales o segregados por ellas.

3 Jim Marcelo Santiago aparece como codirector de 3, y responsable de la cámara y fotografía de las cuatro primeras películas. 
¿Y cómo eran esas representaciones?

Los cineastas surgidos en los años setenta, en su afán por motivar al público al consumo de películas peruanas, apelan al mecanismo de la identificación con los personajes de las películas. Hasta entonces, más allá de las aisladas experiencias de Kukuli (1961) y de las cintas de Armando Robles Godoy, el estándar técnico y expresivo de las "películas peruanas" se asociaba, en el imaginario de los espectadores, con los subproductos filmados en coproducción con México durante los años sesenta. Las audiencias de las ficciones audiovisuales tenían un solo modelo comparativo para ellas: las pautas de representación de las telenovelas mexicanas, argentinas o venezolanas, aclimatadas al medio local para su difusión. Ficciones grabadas en sets inamovibles, frente a escenografías domésticas edificadas con cartón piedra $\mathrm{y}$ con un mobiliario intercambiable entre grabaciones. Pero también con actores engolados, de tono y dicción melodramática, por herencia del patrón de la más retórica interpretación teatral y su derivación telenovelesca.

En 1972, al dictarse el Decreto Ley N. ${ }^{\circ} 19327$, de promoción de la industria cinematográfica, la situación cambia de modo radical. Los cineastas se proponen ofrecer un acercamiento apegado a los estándares realistas de interpretación y ambientación acuñados por el cine internacional.

Francisco Lombardi, José Carlos Huayhuaca, Luis Llosa, Augusto Ta- mayo San Román, pero también el Grupo Chaski, entre otros, apelan a otros rostros, dicciones y léxicos. Recurren a los exteriores naturales para localizar las acciones y ubican a la ciudad de Lima como escenario privilegiado de sus ficciones. En algunos casos, como el de Lombardi, es patente la influencia asimilada de la narrativa literaria realista de la llamada Generación del Cincuenta.

Películas como Cuentos inmorales o Aventuras prohibidas -y, más tarde, Gregorio y Juliana-atraen al público con su apelación a las historias urbanas, las ocurrencias reconocibles y el lenguaje coloquial.

En el episodio Mercadotecnia, o las desventuras de Mercurio, de Augusto Tamayo San Román, incluido en el largometraje Cuentos inmorales (1978), los protagonistas, jóvenes limeños de clase media, intentan vender muebles visitando casas en ambientes distintivos de Barranco o buscan la miraflorina calle Chiclayo, como guiños de reconocimiento para el espectador urbano. La película usa las localizaciones no solo por su presencia plástica o sus valores arquitectónicos. Las representa como signos distintivos de una ciudad y de la pertenencia a ella. En Los amigos, el episodio de Francisco Lombardi realizado para la misma película, los personajes, tacneños de origen, se reúnen en un bar recreo de amplio y aireado solar miraflorino en plena Avenida del Ejército. Más tarde, transitan por una calle del Cercado de Lima rumbo a un bulín. Encarnación 
de los destinos divergentes o contrariados de los migrantes de la provincia costeña en Lima, la película los muestra asimilados a la cultura del criollismo: ebrios, en el momento en el que sellan su amistad permanente -aunque la disuelvan más tarde- entonan El viejo cementerio, canción emblemática de la música popular de la costa del Perú.

Las películas de Eduardo Quispe impugnan ese limeñismo adherido al cine de los setenta y a una franja del actual $^{4}$.

Pero no se limita a cuestionar los recursos que buscan identificar al público con los personajes de las clases medias tradicionales. Impugnan también a los personajes emblemáticos, como los "niños de la calle" del Grupo Chaski, modelados por la sociología, e ignora a los que siguen itinerarios de dolor, a la manera de los relatos de integración simbólica a la ciudad en el estilo de La teta asustada (2009), o de asimilación a ella luego de la experiencia de la violencia, como en Cuchillos en el cielo (2013).
¿Hacia dónde apuntan las películas de Quispe? ¿Cómo son los registros alternativos de comportamientos en los espacios urbanos que las películas muestran?

Los cinco títulos evitan concebir el cine como un lugar de encuentro entre el espectador y su reflejo. No propician la identificación con los personajes de las clases medias y acomodadas provenientes de los distritos del sur, ni con los códigos de comunicación compartidos a pesar de la fragmentación de la ciudad, ni el reconocimiento de los lugares emblemáticos de Lima, ni ofrecen el retrato del "ser como somos". Se alejan también de las formulaciones alegóricas o de simbologías insertadas en el curso de las acciones.

En las películas se impone, más bien, el registro detallista y hasta moroso de comportamientos cotidianos, en una clave impuesta por el aire de los tiempos: el estilo del realismo débil. En la presentación de sus trabajos para una edición artesanal en DVD, Quispe y Marcelo definen la estrategia seguida en 3 :

4 Quizás mañana (2013), de Jesús Álvarez, representa la puesta al día de esa modalidad limeñista en el cine de los últimos años. El distrito limeño de Magdalena se convierte en localización natural y luce una apariencia arbolada, a la vez tradicional y moderna, ya que el periplo afectivo de la pareja protagonista se hace sobre el fondo de parques, fachadas de casas antiguas y residenciales, pero también sobre un puente peatonal desde el que se percibe el tráfago urbano. Se recompone el efecto de reconocimiento e identificación a partir de una dramaturgia de historias mínimas ancladas en jóvenes de una clase acomodada, cuya tipología remite a los casting de las novelas televisivas seriadas para adolescentes. Es un modo de apelar al interés de los espectadores jóvenes de las nuevas clases medias, público objetivo de las salas múltiples, luego de que vastos sectores de la audiencia se alejaran progresivamente del cine en general, y del cine peruano en particular, desde los años noventa. 
Una ciudad, un parque, un momento cualquiera. Un grupo de jóvenes limeños dialogan sobre sus vidas y su intimidad (...) relacionado por el espacio-tiempo del parque, acercándonos a una mirada microscópica de una realidad generacional que oscila entre la ficción naturalista y el documental.

En efecto, más que acciones dramáticas en desarrollo, las escenas muestran gestos, posturas, y movimientos inciertos de los personajes. Los figurantes no recitan las líneas de un guion escrito tratando de reproducir modos lingüísticos y giros propios de un ambiente y un lugar específicos; se encarnan a sí mismos y dialogan sin seguir pautas. La banda sonora es un magma que confunde la música del ambiente, los ruidos y las voces.

Algunos de los diálogos, en las cuatro primeras películas, resultan ininteligibles. Las bandas sonoras perturban y dificultan la inteligibilidad a causa del sonido directo, ofrecido de modo disparejo, opaco y sucio. Es un procedimiento que refuerza las apariencias rugosas de las películas y complementan una narración con fisuras y lagunas en la continuidad, que avanza de modo errático, como duplicando las fragilidades o incertidumbres de los personajes, así como sus derivas emocionales.

Las películas privilegian la observación cercana y el intimismo, así como los planos-secuencias; se interesan por los personajes en tránsito. La luz natural se impone. Los actores, más que componer, se muestran como ellos mismos ante la cámara.
Asimismo, muestran espacios urbanos ceñidos en su localización espacial, por los que transitan personas concretas. "Los jóvenes que muestra Quispe no suelen ser representados con tanta naturalidad en las películas peruanas. Es más, ni siquiera son representados en las películas estrenadas comercialmente. Se trata de jóvenes de sectores medios bajos" (Bustamante, 2010).

Jóvenes que pasan de la figuración colectiva al primer plano para, luego, volver a formar parte de un entorno movedizo. Lima aparece como una ciudad partida en pedazos, que percibimos a través de signos lejanos, como una calle entrevista del Cercado, un cerro en el fondo del horizonte, un puente sobre el río Rímac, el morro de Chorrillos divisado desde el malecón. La ciudad se resiste a las tipificaciones propias de las imágenes de marca.

\section{La deriva obsesiva}

Deriva es "esa forma azarosa de recorrido que conduce a menudo hacia planteamientos negativos" (Imbert, 2010, p. 266). La línea narrativa central de Días de Santiago (2003), de Josué Méndez, sigue la trayectoria marcada por el destino de su protagonista, Santiago (Pietro Sibille), un infante de marina desmovilizado, en un recorrido azaroso, en una deriva permanente por la ciudad.

Combatiente en el Cenepa durante el conflicto fronterizo con el Ecuador, y veterano en la lucha contra Sendero Luminoso, Santiago está de vuelta 
en la vida civil. Aunque la institución militar y el discurso oficial lo consideren un héroe de la patria, la realidad que enfrenta es otra: Lima es la ciudad hostil que impide su reinserción.

Santiago no encaja en el "orden" cotidiano de la ciudad. La "normalidad" del vivir en acecho, agazapado, que la institución militar le inculcó como técnica para sobrevivir en las acciones bélicas, ya no le sirve para nada: en las calles donde transcurre la vida civil los combates también son encarnizados, pero de otra naturaleza.

Días de Santiago tiene dos personajes centrales: su protagonista y la ciudad de Lima, que es el escenario hostil y laberíntico del periplo de Santiago. El soldado pretende encausar el caos urbano aplicando los rigores taxativos de un reglamento castrense, pero la ciudad resiste y se desborda porque también ha sufrido las experiencias de la fractura social y del estrés que sobreviene al trauma.

La narración de la historia no sigue un transcurso lineal y el relato se arma como un rompecabezas conformado por bloques temporales que recusan la continuidad. El registro del entorno limeño, de las culturas del taxi informal, de las academias que preparan para mil oficios, de las discotecas de funcionamiento diurno para jóvenes estudiantes, y de la violencia familiar, se entremezclan con las imágenes que dan cuenta de los automatismos de Santiago ${ }^{5}$.

5 Chicha tu madre (2006), de Gianfranco Quattrini, muestra a Lima vista desde la experiencia cotidiana del "taxeo". Su protagonista, Julio César (Jesús Aranda), conduce un taxi mientras intenta sobrellevar sus múltiples problemas personales.

La expresión "chicha tu madre" del título alude a la invectiva de rechazo que desea pronunciar el protagonista ante cada contratiempo. Pero también refiere una forma cultural basada en la informalidad (la cultura "chicha") y a un modo de acomodarse o de encontrar un precario lugar en medio de la turbamulta de la urbe. La marginalidad es aquí una forma de impotencia para obrar y conseguir un cambio de vida.

Tiempos de confusión y caos urbano que obligan a transitar, en taxis y microbuses, por una Lima fotografiada con el grano expuesto, sobre todo de noche, resaltando los reflejos de las luces de colores sobre las superficies lustrosas o los vidrios de los autos. Los recorridos del taxi de Julio César marcan la accidentada topografía de la ciudad mientras reconocemos los signos de la cultura urbana, desde los carteles que anuncian fiestas "chicha" hasta las inscripciones emotivas en los vehículos de transporte público. La banda sonora se colma de música tropical de fusiones melódicas. Lima muestra sus calles, mercados, prostíbulos y los lugares donde se practica el fútbol. Los trazos de la mirada costumbrista están presentes, pero atenuados en la identificación y sometidos a un tratamiento para nada exultante. La representación de los espacios y ambientes urbanos, ásperos y densos en su presencia física, se ofrece con la acentuación del hiperrealismo de la fotografía. Las imágenes de la película naturalizan la experiencia de transitar por las escenografías abigarradas de la ciudad. 
Lima aparece registrada con acentos documentales $\mathrm{y}$, más tarde, con distorsión expresionista. El tratamiento visual de Juan Durán pasa del realismo fotográfico, con el grano de la emulsión expuesto, en las escenas del personaje en su deriva por la ciudad bullente, a la estilización de las imágenes del protagonista practicando ejercicios militares en una playa. En el transcurso de la película se alternan, en sucesión arbitraria, las imágenes en blanco y negro con las de color. Las disociaciones cromáticas duplican las fisuras que separan a Santiago de su entorno. La cámara, en movimientos de seguimiento, reproduce su zigzagueante trayectoria. En la banda sonora, el tormentoso flujo de la conciencia expresa una subjetividad atribulada.

Días de Santiago sigue la travesía delirante de un personaje que lamenta la pérdida de un orden autoritario pero comprensible para él, estrellándose contra la nueva fisonomía de una sociedad que cultiva el egoísmo como valor primordial. Las diferencias entre el reiterativo discurso de Santiago y las realidades que confronta marcan contrastes irrisorios y exasperantes al mismo tiempo.

En Lima, Santiago no encuentra posibilidades de asimilarse a un colectivo ni de construirse como un sujeto. Se le niega el crédito y, por ende, la posibilidad de acceder al consumo que moviliza a los ciudadanos. Es expulsado de los lugares públicos a los que acude para cimentar lazos sociales. Asiste al deterioro de unas relacio- nes familiares en las que no se puede reconocer. Percibe que los "héroes de la patria", como él, solo tienen abiertos los caminos del suicidio -como uno de sus compañeros- o el robo en banda organizada. Descubre que su masculinidad está "mancillada" por los nuevos tiempos (Saona, 2008).

Al final de la película, luego de descubrir al padre incestuoso, ese espejo opaco en el que ya no podrá reflejarse, símbolo del fracaso absoluto de su deseo de integración social, Santiago se frota el rostro con una pistola. $\mathrm{Ni}$ el arma lo puede salvar: Santiago no será héroe, ni ciudadano, ni consumidor, ni "salvador de doncellas", ni sujeto de derechos en una sociedad "ordenada", "moderna" y liberal.

\section{Derivas en la marginalidad}

Las acciones de Paraíso (2010), primer largometraje de ficción de Héctor Gálvez, transcurren en una población periférica fundada por desplazados ayacuchanos durante los años de la violencia política. Es un lugar ubicado en las afueras del casco urbano, cerca a Cajamarquilla, al que se llama, acaso con ironía, Jardines del Paraíso.

Ahí viven cinco jóvenes, Joaquín (Joaquín Ventura), Mario (José Luis García), Sara (Gabriela Tello), Antuanet (Yilliana Chong) y Lalo (William Gómez). Ellos observan con incertidumbre los rumbos que toman sus destinos individuales, atenazados por la pobreza y la marginalidad. 
Es central la presencia del espacio terroso y reseco de Jardines del Paraíso. Su topografía es una expresión simbólica de las trayectorias de los protagonistas. En el desarraigo, las extensiones polvorientas son tierra de nadie.

En la superficie del lugar se reconocen espacios aislados, que congregan a los personajes. Uno de ellos se asocia con la muerte. Un sitio donde, de modo paradójico, todo comienza. El grupo se dirige hacia allí en un rito conmemorativo: es la tumba del llamado Che Loco, líder y compañero respetado, asesinado en una confrontación de pandillas. Sus amigos acuden ante la sepultura, ubicada en medio de la planicie reseca, para ofrecerle "pagos" o tributos, dejando panes, caramelos y licor. Otro lugar de reconocimiento colectivo está enclavado como símbolo del asentamiento: es el entorno de un árbol reseco que se mantiene en pie pese a la aridez del sitio.

Otros dos espacios se descubren en la zona. El lugar de altura que preside el asentamiento: una inmensa roca con perfil de inca que domina el espacio. Y las huacas de la planicie.

Hasta la tumba del amigo y hasta el árbol resistente llegan los jóvenes para rendir tributo al pasado del grupo y a un presente de urgida supervivencia en esa periferia de la ciudad. Son espacios a los que acuden para renovar sus vínculos comunes y fidelidades personales.

Las huacas y el inca pétreo, en cambio, forman espacios singulares: dan cuenta de identidades desacreditadas, puestas en cuestión.

La película se ambienta en ese lugar ubicado en los márgenes. Los personajes viven ahí la experiencia de la exclusión. Vista desde las alturas de Jardines del Paraíso, Lima luce lejana e indolente.

Las imágenes de la Lima del Cercado y de los distritos tradicionales se mantienen fuera del campo visual. En Jardines del Paraíso no existen dependencias administrativas ni de vigilancia, sanción, represión o control. Es un mundo arrinconado, alejado del Estado y sus autoridades. Por eso, los protagonistas construyen sus propias normas sociales en medio de la privación y las estrecheces. Un orden que se organiza sobre correspondencias informales (Bedoya, 2013).

A la ciudad ausente solo cabe mentarle la madre a gritos.

Descendientes de los pobladores andinos que sufrieron las consecuencias del conflicto armado interno, los personajes de Paraíso buscan un entronque con la línea sucesoria o de filiación que interrumpió la violencia. Esa que ellos no encararon, pero que recibieron como memoria vicaria o experiencia heredada; como posmemoria (Hirsch, 2012).

A pesar de ser limeños legítimos de segunda generación, aún no logran resolver su pertenencia a la tierra que los acoge ni el reclamo de la filiación que les corresponde. Para ese grupo de jóvenes, ajustarse a las demandas del pasado remoto supone respetar el 
mandato de la roca con perfil de inca que se halla en las alturas del lugar. La leyenda oral, heredada de los primeros migrantes llegados a la zona, asegura que ese inca, de presencia hierática, vigila el orden de Jardines del Paraíso: su imponente perfil protege la zona del saqueo de los tesoros que yacen en las huacas aledañas. La mirada pétrea e impenetrable del inca ahuyenta a los huaqueros codiciosos que pretenden encontrar el precioso "tapado" enterrado por los españoles: el oro arrebatado al imperio incaico y escondido ahí, en esa planicie.

Esa roca es, pues, la depositaria de una identificación colectiva y una identidad construida en los tiempos difíciles de la inmigración. El relato de su poder es una pervivencia de la mitología andina en el arenal costeño de la capital. Y es una presencia que, acaso, sustituye la ausencia del Estado.

Pero esa figura rica en valores simbólicos no es más que la representación de un poder colapsado y anacrónico. Ya nadie, en las nuevas generaciones, llama a la movilización colectiva en nombre del inca ni invoca el imaginario del "Pachacuti" restaurador del orden original quebrado por la Conquista. Basta echar una mirada al horizonte del arenal para percibir que las huacas fueron saqueadas una y mil veces y que las riquezas de Jardines del Paraíso resultan ilusorias, si es que fueron, alguna vez, reales.

La figura del inca, ficción fundacional del lugar y sustento de una iden- tidad vigente para los desplazados ayacuchanos, no lo es más para sus hijos, nuevos y desvalidos limeños. Cuestionada la narrativa de la autoridad simbólica incaica y difundido el descreimiento respecto de los valores heredados del pasado histórico, los jóvenes miran hacia el entorno familiar y se preguntan por el valor real de los progenitores y por la autenticidad de sus vínculos cercanos.

Los jóvenes de Paraíso no se entroncan con el inca, ni con la ciudad, ni con "padre" alguno.

¿Qué queda, entonces, para ellos?

Marcharse del lugar y encontrar el "paraíso" en otro sitio: acaso buscando en Lima, la ciudad lejana, las posibilidades de "afiliación" (Said, 2004), convirtiéndose allí también en migrantes perpetuos.

\section{Derivas por hostales, cabinas y huacas}

Videofilia (y otros sindromes virales) (2015), segundo largometraje de Juan Daniel F. Molero, es una excursión, de ambiciones corales, por modos de consumo diversos del universo virtual.

Limeños jóvenes y variopintos se relacionan a partir de la fruición más o menos compulsiva de la red y sus contenidos. Espectadores de porno, maníacos del chat, navegantes de páginas sobre trascendencia y escatología, usuarios de redes sociales, constructores de gráficos animados, devotos 
de los juegos virtuales, poseídos por adicciones al ciberespacio, empresarios informales de pornografía pirata o registrada de modo clandestino e ilegal, entre otros, van trazando una ronda que combina lo ligero, lo humorístico y lo grave.

El interés principal de Videofilia... es la descripción del entorno de la juventud de la clase media limeña que visita cabinas de Internet, tiene encuentros eróticos grabados en hostales, se cita en chifas al paso, frecuenta centros comerciales donde se rinde tributo al si- mulacro en versión cosplay, alimenta a Cholotube y sitios de vídeo porno amateur, o consume ácido en las alturas de una huaca de Magdalena del Mar o de cualquier otro barrio tradicional. Una modernidad que contrasta -o se completa- con el apego a supersticiones arcaicas, creencias esotéricas o prácticas culturales ancestrales de los Andes, como el examen de los presagios contenidos en las entrañas de un cuy.

Es el registro de la modernidad mestiza o híbrida sobre la que se asienta la "nueva" Lima6.

6 Microbús (2013) y ¡SOPLA! (2014), mediometrajes de Alejandro Small, muestran sendas derivas por la ciudad. En la primera, un grupo de jóvenes de la clase media se lanza a un recorrido nocturno por las calles de Miraflores. No hay objetivos ni metas en su deambular; solo impulsos que los conducen hacia una trayectoria sinuosa, que tiene algo de juego, de pérdida de rumbo y de complicidad de grupo. Escuchamos sus diálogos, coloquiales y directos, más bien insustanciales, dichos con los ritmos y entonación de los muchachos limeños de los distritos mesocráticos del sur. Pero sobre todo los vemos relacionarse con esas calles que se van despoblando paulatinamente, hasta que quedan solo ellos y el entorno más reducido de la ciudad, a la que no sienten propia. Miraflores no les pertenece.

Por eso, del juego o del paseo zigzagueante -el recorrido que se convierte en deriva- pasan a la agresividad de los golpes y patadas lanzadas contra una pared para, luego, echarse a reposar en un parque. La película se modula a partir de pulsiones opuestas. Los espacios acogedores se vuelven hostiles para luego convertirse en lugares de reunión que convocan una extraña y áspera ternura. Y los personajes pasan de la broma relajada y el "vacilón" de grupo a la expresión de una rebeldía que se mantiene latente o se expresa con una furia acaso gratuita, de puro gesto y pose beligerante.

La fotogenia de la noche, captada por César Fe con sensibilidad impresionista, da cuenta de las luces de colores del neón publicitario, pero también de la neblina costera y miraflorina que pulveriza las luces intensas. Las sombras de los cuerpos de los actores se recortan en contraluces o aparecen filtrados por una neblina saturada de amarillo.

La travesía del mediometraje ¡SOPLA! (2014) es, más bien, imaginaria, cercana a lo "fantástico". Ambientada en el distrito limeño y popular de La Victoria, la película fabula una historia que mantiene un pie en el wéstern y el otro en el musical, sin evadir las referencias al género criminal, en esa colorida variante que mezcla acción y melodías latinas, o que se acerca a la tonalidad de ciertas películas del blacksploitation de los años setenta. 


\section{Lima distópica}

El limpiador (2012), primer largometraje de Adrián Saba (1988), narra el itinerario de Eusebio (Víctor Prada), que enfrenta con carácter estólido una inexplicable plaga que diezma a los habitantes de Lima.

Un temple forjado en el ejercicio cotidiano de su oficio: el de empleado sanitario que recoge los cuerpos de las víctimas y desinfecta los lugares donde cayeron, con el fin de cortar la diseminación de la plaga. Es, pues, un "limpiador".

Mientras "limpia" una casa solitaria descubre a un niño de ocho años: se llama Joaquín (Adrián Du Bois), y está escondido en un clóset desde que su madre cayó muerta, presa de la epidemia. Eusebio se hace cargo del niño tras fracasar en su intento de llevarlo a un orfanato. Empieza una relación entre dos personajes excéntricos y marginales. Dos solitarios abandonados a su suerte en una Lima peligrosa.

El limpiador, pese a su registro casi documental, se afilia a la ficción distópica.
Lima luce asolada. Ya ocurrió el desastre, pero desconocemos su origen y la naturaleza de la plaga; tampoco sabemos de su duración o extensión, ni de la mortalidad que ha provocado. Eusebio y su pequeño compañero se desplazan por una Lima singular, escenario de una austera película de ciencia ficción.

El limpiador ofrece el retrato al vacío de Lima. De ella solo reconocemos signos y algunos rasgos del perfil urbano. El resto son indicios y pura extrañeza. Siguiendo la tradición de las películas de ciencia ficción posapocalíptica, las escenografías naturales elegidas son las que distinguen el perfil de la ciudad.

Los recorridos de los personajes tienen como fondos los emblemas de la modernidad urbana, edificados como signos de los marcadores económicos favorables en el Perú de la segunda década del siglo XXI: el metro de Lima, los estacionamientos subterráneos de amplios edificios, el remodelado Estadio Nacional, el parque de las aguas. Pero todos ellos lucen vacíos, como si los limeños hubieran

Con desparpajo, Small fusiona géneros e inventa una historia de una banda de gánsteres, llamados "Los Salsa", que emplean instrumentos musicales que son también armas de fuego. Con ellos amenazan a los clientes de las casas de cambio, multiplican atracos y organizan singulares coreografías que no se distinguen por su armonía o por su perfección técnica. El barrio victoriano de Matute hace las veces de un pueblo de un Oeste de construcciones horizontales y azoteas polvorientas donde conviven bandoleros del imaginario cinéfilo con hinchas del club de fútbol Alianza Lima. 
desertado de los lugares distintivos de su "marca ciudad".

El recorrido por Lima sigue una curva descendente. Empieza en el puente elevado que une los malecones de Miraflores y termina a la orilla del mar. En el ínterin, la ciudad se deja ver en forma transversal desde el recorrido de un tren eléctrico de marcha fantasmal. Tres hitos topográficos anclan el sentido de la epidemia y describen su extensión: en los cementerios en los que el niño busca a su madre, el mal iguala a las víctimas, sin distinciones. En uno de esos cementerios se inhuma en la tierra, bajo los jardines; en otro, en nichos construidos en cuarteles; en el tercero, sobre las laderas rocosas de un camposanto popular. La idea evoca el final de Caídos del cielo, de Lombardi.

La austeridad de los recursos formales marca el temple estilístico de la película. Los encuadres, siempre fijos, tienden a la frontalidad y el equilibrio. La composición visual construye espacios de líneas rígidas y disposiciones geométricas.

La extrañeza de las situaciones y lugares se refuerza con una luz fría, de matices metálicos.

Las actuaciones son parcas, contenidas e interiores. La intriga es mínima y las situaciones carecen de sustancia dramática fuerte. El limpiador ofrece una lograda poética de la desolación.

Aquí también, como en tantas otras películas peruanas recientes, Lima es la ciudad de las "derivas".

\section{Referencias}

Arellano, R. (2004). Ciudad de los Reyes, de los Chávez, los Quispe... Una visión social y de mercado de la nueva urbe latinoamericana. Lima: Epensa.

Bedoya, R. (2013). Paraíso. El orden desde los márgenes. En C. O'Neill de la Fuente (Eda.), El derecho va al cine. Lima: Universidad del Pacífico.

Bustamante, E. (2010). ¿Cuál es el nivel expresivo del cine que se hace en el Perú? Páginas del diario de Satán [blog]. Recuperado de http:// paginasdeldiariodesatan.blogspot. com/2010_02_01_archive.html

Del Pino, P. (2013). Introducción: etnografías e historias de la violencia. En P. del Pino y C. Yezer, Las formas del recuerdo. Etnografías de la violencia política en el Perú. Lima: Instituto de Estudios Peruanos.

Gaudreault, A., y Marion, P. (2013). La fin du cinéma? Un média en crise à lière du numérique. París: Armand Colin.

Hirsch, M. (2012). The generation of postmemory: writing and visual culture after the Holocaust. Nueva York: Columbia University Press.

Imbert, G. (2010). Cine e imaginarios sociales. Madrid: Cátedra.

Matos Mar, J. (1984). Desborde popular y crisis del Estado. El nuevo rostro del Perú en la década de 1980. Lima: Instituto de Estudios Peruanos.

Portocarrero, M. G. (1993). Los nuevos limeños: sueños, fervores y caminos en el mundo popular. Lima: SUR. 
Rombes, N. (2009). Cinema in the Digital Age. Nueva York: Wallflower, Columbia University Press-ebook.

Said, E. (2004). El mundo, el texto y el crítico. Barcelona: DeBolsillo.
Saona, M. (2008). Cuando la guerra sigue por dentro: Posmemoria y masculinidad entre Yuyanapaq y Días de Santiago. Inti. Revista de Literatura Hispánica, 67(1). 